Estimación multianual del ámbito hogareño

de un tapir de Baird (Tapirus bairdii) en la Selva Maya

\title{
Insights into the multiannual home range of a Baird's tapir (Tapirus bairdii) in the Maya Forest
}

\author{
Rafael Reyna-Hurtado ${ }^{1 *}$, Mauro Sanvicente-López² ${ }^{2}$ Jonathan Pérez-Flores ${ }^{3}$, \\ Natalia Carrillo-Reyna ${ }^{4}$ and Sophie Calmé ${ }^{5,3}$
}

\footnotetext{
1 El Colegio de la Frontera Sur, Unidad Campeche, México. Av. Rancho, Polígono 2A, Cd. Industrial, Lerma 24500. Campeche, Campeche, México. Email: rreyna@ecosur.mx (RR-H).

${ }^{2}$ El Colegio de Posgraduados, Campus Puebla, 72760. Ciudad de Puebla, Puebla, México. Email: sanvicentemauro@yahoo.com. $\underline{m x}$ (MS-L).

${ }^{3}$ El Colegio de La Frontera Sur, Unidad Chetumal. Av. Centenario Km 5.5 Carretera Calderitas, 77900. Chetumal, Quintana Roo, México. Email: johnspf77@yahoo.com.mx (JP-F).

${ }^{4}$ El Colegio de la Frontera Sur, Unidad Chiapas. Carretera Panamericana y Periférico Sur s/n, 29290. San Cristóbal de Las Casas, Chiapas, México. Email: atty_05@hotmail.com (NC-R).

${ }^{5}$ Universite de Sherbrooke, Faculté des Sciences. Département de biologie. 2500 avenue de I'Université, J1K 2R1. Sherbrooke, Québec, Canada. Email: sophie.calme@usherbrooke.ca (SC).

${ }^{*}$ Corresponding Author
}

\begin{abstract}
We report home range estimates of an individual Baird's tapir (Tapirus bairdii) recorded from May 7, 2011 to September 2015 at the Calakmul Biosphere Reserve in Southern Mexico. The tapir was captured and equipped with a VHF collar in a pond within the reserve. The signal failed to transmit in the following month but with the help of a network of camera traps deployed in nearby water bodies we monitored this individual during four years and a half. We have estimated home range by the Minimum convex polygon method and also by constructing a buffer around camera traps locations where this animal was photo-captured. With few available records $(<30)$ but spanned over four years the Minimum convex polygon estimate for all locations resulted in $23.9 \mathrm{~km}^{2}$. When we constructed a buffer around camera trap locations we estimated a home range of $39.9 \mathrm{~km}^{2}$ with a core area of $4.1 \mathrm{~km}^{2}$. Maximum distance dispersed from this tapir was $10.5 \mathrm{~km}$ from its original location. The home range estimates reported here are larger than previously reported for this species. This is the first report on the home range, travel capacity, and distances for the Baird's tapir in the Calakmul Region.
\end{abstract}

Reportamos estimaciones del tamaño del ámbito hogareño de un individuo de tapir de Baird (Tapirus bairdii) en la Reserva de la Biósfera de Calakmul desde el 7 de mayo del 2011 hasta septiembre del 2015. El tapir fue capturado en una "aguada" dentro de la reserva y se le puso un collar de radiotelemetría VHF que funcionó solo unas semanas. Con ayuda de una red de cámaras trampas instaladas en cuerpos de agua hemos monitoreado movimientos de éste individuo por cuatro años y medio. Estimamos el ámbito hogareño a través del método del Polígono mínimo convexo y construyendo una área buffer alrededor de los sitios donde ha sido foto-capturado. Con los pocos registros obtenidos $(<$ 30), pero que se extienden durante cuatro años y medio y utilizando el Polígono mínimo convexo y considerando todos los registros desde que este individuo fue capturado, estimamos un ámbito hogareño de $23.9 \mathrm{~km}^{2}$. Cuando construimos un buffer alrededor de dichos puntos estimamos un ámbito hogareño de $39.9 \mathrm{~km}^{2}$ con un área núcleo de $4.1 \mathrm{~km}{ }^{2}$. La distancia máxima de dispersión fue de $10.5 \mathrm{~km}$ desde su ubicación original. Los ámbitos hogareños estimados en esta investigación son más grandes que los reportados para esta especie en otros estudios. Este es el primer reporte de ámbitos hogareños, capacidad de movimientos y distancias de desplazamiento para el tapir de Baird en México.

Key words: camera traps; Calakmul Biosphere Reserve; Calakmul ponds; Minimum convex polygon; Radiotelemetry.

๑ 2016 Asociación Mexicana de Mastozoología, www.mastozoologiamexicana.org 


\section{Introduction}

The Baird's or Central American tapir (Tapirus bairdii) is an endangered Neotropical species of the current low diverse order Perissodactyla. Found originally from Mexico to Northern Ecuador, its historical range has been reduced considerably (Castellanos et al. 2008). It has been determined that the largest population from the whole distribution is the one living in the Maya Forest, a tropical forest shared between Mexico, Guatemala and Belize (Naranjo 2009). The Calakmul Biosphere Reserve (CBR), located at the center of the Maya Forest, is the largest protected tropical forest in Mexico with almost no significant human perturbation in the last 1100 years (Reyna-Hurtado et al. 2009).

Within the paradigm of movement ecology (Nathan et al. 2008), the movement of animals in the wild and decisions they take are of fundamental importance to understand aspects of habitat use, feeding habits, dispersing abilities, use of spatial memory, and several other ecological process that deal with movement. Baird's tapir movement ecology is virtually unknown except for the studies in Corcovado National Park, Costa Rica, where several tapirs were radio collared and home range and movement patterns were determined for several year (Foester 2001; Foester and Vaughan 2002). In Mexico, density, relative abundance, habitat use and human impact on tapir populations have been determined for the following protected areas: a) Montes Azules Biosphere Reserve, Chiapas (Naranjo 2002); b) El Triunfo, Chiapas (Carrillo- Reyna et al. 2015b276); c) Chimalapas region, Oaxaca (Lira et al. 2012); and d) Calakmul Biosphere Reserve, Campeche (Perez-Cortez et al. 2012, Carrillo- Reyna et al. 2015b275). Baird's tapir potential habitat has been modeled for the Yucatán Peninsula (Carrillo- Reyna et al. 2015b275).

To fill gaps in knowledge, from 2010 to 2012 we tried to capture and follow a Baird's tapir in the CBR with the aim of determine their movement patterns in this semi-dry environment where water is scarce over the dry season. Here we present estimations of home range and distances travelled by a Baird's tapir that was captured and followed with a set of camera traps deployed strategically in selected ponds for four and a half years in the core area of the CBR in Southern Mexico.

\section{Methods and Materials}

This study was conducted under the permission of the corresponding authorities (see Acknowledgement section) in the CBR in Campeche, Mexico, in the core of the Maya Forest. CBR is a semi-perennial tropical forest relatively undisturbed since abandoned by the Mayans 1100 years ago with tree heights generally between 15 and $25 \mathrm{~m}$ (Pennington and Sarukhan 1998). Today CBR is the largest protected tropical forest of Mexico with $7,238 \mathrm{~km}^{2}$ and with human activity limited to tourism centered on archeological ruins. Hunting or extraction of timber or non-timber products is prohibited (Reyna-Hurtado et al. 2009). There are no major rivers in the CBR and most water percolates from underground due to the karst or limestone soils with limited standing water known as "aguadas", which constitute the only water source for humans and wildlife in the dry season (Reyna-Hurtado et al. 2010).

As part of a large project founded by Conacyt (Mexican Council of Science) we captured a wild individual of Baird's tapir with a combination of Butorphanol and xilazine hydrochloride (Hernandez-Divers et al. 1998). We used a remote delivery system (Daninject Inc. Austin, TX) to anesthetize the tapir and to place a VHF radiotelemetry collar that failed to send signal after several days of being deployed. The tapir was subsequently recorded only when it appeared in the set of camera traps that were set up at six "aguadas" of the CBR.

We estimated home range using the Minimum convex polygon method (Seaman and Powell 1996; Kernohan et al. 2001). Minimum convex polygons are simple and easy to calculate and basically encircle areas where the animals have been observed. It is a highly common method that is easy to compare among different studies (Kernohan et al. 2001). Additionally, due to the fact that most of the records used in this study came from photo-captures in camera traps locations 
(Reconyx RapidFire 800) we decided to emulate the analysis used to estimate density for tiger (Panthera tigris; Karanth and Nichols 1998) and jaguars (Panthera onca; Silver et al. 2004) where a potential area visited by the animal is estimated through constructing a buffer of half the size of the maximum distance moved around the camera traps where the animal have been recorded (Karanth and Nichols 1998). We estimated the maximum distances moved from a subset of camera traps where we recorded the tapir from November 2011 to September 2015 and constructed a buffer of half the size of the single maximum distances moved. We estimated the area of the combined buffer polygons and presented as another estimation of home range.

\section{Results}

We captured a subadult male tapir on May 7, 2011. The animal was released with an attached radiotelemetry collar. However, the collar failed after 20 days due to unknown causes. Therefore, with six camera traps strategically positioned in ephemeral ponds of the CBR we obtained additional records from this individual that was recognized due to the presence of the collar. We recorded the presence of this tapir in 30 events from May 2011 to September 2015. The tapir spent a few months around the site where it was captured ("Aguada Bonfil"). Later in the same year (November 2011) moved to a set of ponds 8 km away, "Aguada Verde", "Baños", "Aguada Calakmul" and "Corriente Calakmul", that we refer to as the dispersed area. The individual remained there until the end of the study (September 2015), with the exception of a single trip back to "Aguada Bonfil" that last two days. The individual showed a marked preference for "Aguada Verde" with $50 \%$ of observations. The distances between "Aguada Bonfil" and "Aguada Verde" is $7.8 \mathrm{~km}$, while the distance from "Aguada Bonfil" to the furthest "aguada" where the animal was recorded ("Baños") is $10.5 \mathrm{~km}$. For the subset of data of those sites where it has been recorded since November 2011 (the dispersed area) the maximum distances it has moved in a straight line was $4.1 \mathrm{~km}$; therefore we used half of this maximum distance $(2.08 \mathrm{~km})$ as a distance to construct a buffer around these points for purposes of estimate a potential home range.

We estimated a home range of $23.9 \mathrm{~km}^{2}$ from a Minimum convex polygon built using all records (Table 1, Figure 1). Considering only the sites where we have recorded the tapir since it moved to a new area (the dispersed area; November 2011 to September 2015 with the exception of a single trip to "Aguada Bonfil" this tapir did in April 16 and 17 of 2012). We found a large variation in home range estimates, from a conservative estimate of $4.1 \mathrm{~km}^{2}$ as the Minimum convex polygon around sites, to $39.8 \mathrm{~km}^{2}$ considering the buffer around these points of half the size $(2.08 \mathrm{~km})$ of the maximum distances the tapir moved during this time (Table 1, Figure 1).

\section{Discussion and Conclusions}

Due to limited information on home range on this species here we present estimates of home range of an individual tapir based on few locations but gathered over a long period of time and that shows a consistent use of some specific sites at the Maya Forest. Considering the home range estimates of $1.25 \mathrm{~km}^{2}$ to $10.7 \mathrm{~km}^{2}$ for tapirs in Corcovado National Park of Costa Rica (Foester 2001; Foester and Vaughan 2002) our conservative estimate of the Minimum convex polygon of the area

Table 1. Home range estimations based in records obtained from May 2011 to September 2015 of an adult Baird's tapir in the Calakmul Biosphere Reserve, Campeche Mexico.

\begin{tabular}{lrr}
\hline \multicolumn{1}{c}{ Home Range Estimation Method } & Dates & Area (Km $\left.{ }^{2}\right)$ \\
\hline Minimum convex polygon of all tapir records since it was captured. & May 2011-September 2015 & 23.93 \\
Minimum convex polygon of tapir records only from area where it dispersed. & November 2011 to September 2015 & 4.16 \\
Area buffer around points of area where it dispersed. & November 2011 to September 2015 & 39.87 \\
\hline
\end{tabular}


where the tapir dispersed $\left(4.1 \mathrm{~km}^{2}\right)$ fits well in this interval. However, the estimates of the Minimum convex polygon for all locations $\left(23.9 \mathrm{~km}^{2}\right)$ and from the buffer around the area where the animal dispersed $\left(39.8 \mathrm{~km}^{2}\right)$ are the largest reported for this species. These estimates are even larger than those reported for Tapirus terrestris where a mean of $4.7 \mathrm{~km}^{2}$ and a maximum home range of $14.2 \mathrm{~km}^{2}$ were estimated (using Fixed Kernel and Minimum convex polygon methods) from 19 individuals followed in Brazil from periods of 8 to 36 months (Medici 2010). Other estimates of home range on $T$. terrestris are also lower than the ones obtained in Calakmul; for example in the dry forest of Bolivia (Chaco region) five individual averaged $2.4 \mathrm{~km}^{2}$ with a maximum of $3.0 \mathrm{~km}^{2}$ after 29 months of radiotelemetry work (Noss et al. 2003). Our estimates of Calakmul are also larger than the $3.5 \mathrm{~km}^{2}$ (Kernel method) and $2.5 \mathrm{~km}^{2}$ (Minimum convex polygon) reported for an individual of Tapirus pinchaque in the Colombian Andes (Lizcano and Cavelier 2004), or $8.8 \mathrm{~km}^{2}$ for three individuals of same species in the Ecuadorian Andes (Downer 1996).

The limited data in this study with only one individual studied prevent a more detailed elaboration, but water searching may be triggering its movement among CBR ponds. This was demonstrated by four white-lipped peccary (Tayassu pecari) herds in the same location where water sources determined their movement during the dry seasons of 2005 and 2006 (ReynaHurtado et al. 2012). This study also found that the almost $8 \mathrm{~km}$ that separated "Aguada Bonfil" from "Aguada Verde" were travelled by this tapir in less than 24 hours (from the 16th to 17th of April 2012) showing the orientation abilities of this individual and indicating the possibility of using spatial memory given the linearity and precision of its movements.

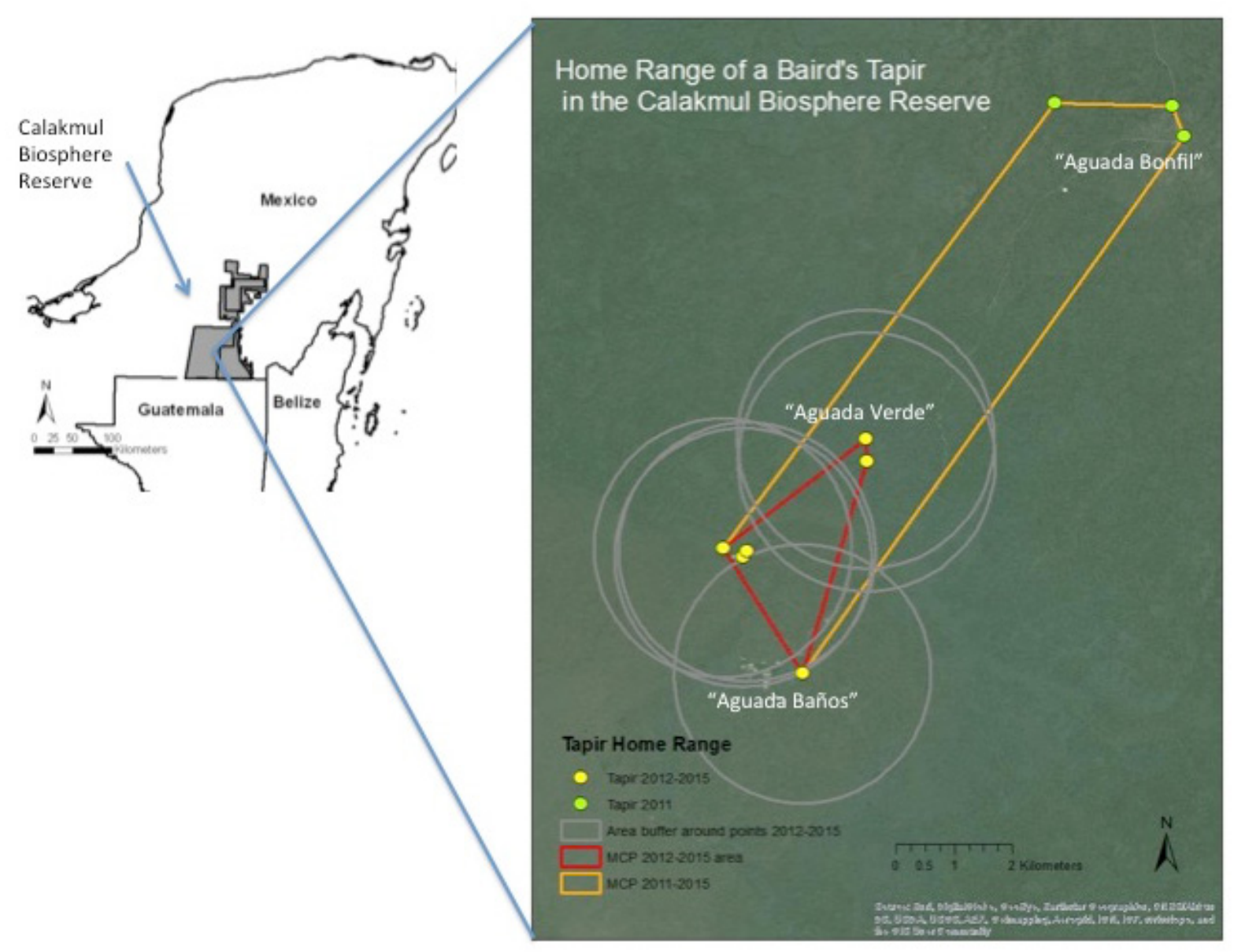

Figure 1. Records of presence of a Baird's tapir (May 2011 - September 2015) with Minimum convex polygon of all locations (May 2011 to September 2015), of only the area where the individual dispersed (November 2011 to September 2015) and polygon of home range estimated using a buffer of half the maximum distance moved of the locations where it dispersed (November 2011 to September 2015). 
Baird's tapir is an endangered species with limited information available about its ecology requirements, including home range and movement patterns; this information is urgently needed to elaborate conservation plans and actions. Our study is important because, even it is limited in frequency of observations, it spans over four and a half year and analyses indicated that home ranges and distances travelled by this species might be larger than previously reported. This is a topic that deserves future research on this endangered species.

\section{Acknowledgments}

We thank Conacyt-Semarnat for providing funds to this study through a grant to $\mathrm{RR}-\mathrm{H}$ and S-C. El Colegio de la Frontera Sur, unidad Campeche and McGill University provided funds and equipment to $\mathrm{RR}-\mathrm{H}$ to follow the tapir over all the years. N. Arias provided fundamental skills to achieve success on this project. J. Zuñiga, C. Coutiño, D. Sima from the Calakmul Biosphere Reserve office (CONANP) provided invaluable help during this study. E. Rojas-Flores, A. Reyna-Rojas and E. Reyna-Rojas provided invaluable time to finish this study. Two anonymous reviewers and the associated editor provided valuable suggestions and comments on an earlier version of this contribution. This study was carried out with the permits granted by the Dirección General de Vida Silvestre (Mexican Wildlife Service) number: SGPA/DGVS/02665/13 and with the authorization from Calakmul Biosphere Reserve Authorities and from the Ethics committee from El Colegio de la Frontera Sur.

\section{Literature Cited}

Carrillo-Reyna, N., R. Reyna-Hurtado, and B. Schmook. 2015a. Abundancia relative y selección de hábitat de Tapirus bairdii en las reservas de Calakmul y Balam Kú, Campeche, México. Revista Mexicana de Biodiversidad 85:202-207.

Carrillo-Reyna, N., H. Weissenberger, and R. Reyna-Hurtado. 2015b. Distribución potencial del Tapir Centroamericano en la península de Yucatán. Therya 6:575-596.

Castellanos, A., C. Foerester, D. J. Lizcano, E. Naranjo, E. Cruz-Aldan, I. Lira-Torres, R. Samudio, S. Matola, J. Schipper, and J. Gonzalez-Maya. 2008. Tapirus bairdii. The IUCN Red List of Threatened Species 2008, (www.iucnredlist.org; accessed in September 15, 2015).

Downer, C. C. 1996. The mountain tapir, endangered "flagship" species of the high Andes. Oryx 30:45-58.

Foerster, C. 2001. Results of a five-year telemetry study of Baird's tapir in Costa Rica. P. 9. Proceedings of the First International Tapir Symposium. San Jose, Costa Rica.

Foerster, C., and C. Vaughan. 2002. Home Range, Habitat Use, and Activity of Baird's tapir in Costa Rica. Biotropica 34:423-437.

Hernández-Divers, S., J. Bailey, R. Aguilar, D. Loria, and C. Foerster. 1998. Cardiopulmonary effects and utility of a butorphanol/xylazine/ketamine anesthethic protocol for immobilization of free-ranging Baird's tapir (Tapirus bairdii) in Costa Rica. Pp. 41-48 in Proceedings of the American Association of Zoo Veterinarians Conference.

Karanth, K. U., and J. D. Nichols. 1998. Estimation of tiger densities in India using photographic captures and recaptures. Ecology 79:2852-2862.

Kernohan, B. J., R. A. Gitzen, and J. J. Millspaugh. 2001. Analysis of animal space use and movement. Pp. 125-166 iln Radio Tracking and Animal Populations (Millspaugh, J. J., and J. M. Marzluff, eds). Academic Press. San Diego, U.S.A.

LiRa-Torres, I. AND M. Briones-Salas. 2012. Abundancia relativa y patrones de actividad de los mamíferos de los Chimalapas. Oaxaca, México. Acta Zoológica Mexicana (n. s.) 28:566-585. 
Lira-Torres, I., J. Pérez-Flores, M. Briones-Salas, and R. Carrera-Treviño. 2014. Métodos de captura e inmovilización química del tapir centroamericano (Tapirus bairdii) en el sureste de México. Quehacer Científico en Chiapas 9:35-46.

Lizcano, D., and J. Cavelier. 2004. Using GPS Collars to Study Mountain Tapirs (Tapirus pinchaque) in the Central Andes of Colombia. Tapir Conservation 13:18-23.

Medicı, P. 2010. Assessing the Viability of Lowland Tapir Populations in a Fragmented Landscape. Durrell Institute of Conservation and Ecology (DICE). University of Kent. Canterbury, United Kingdom.

Mendoza Ramírez, E., and J. P. Carbajal Borges. 2011. Avances y perspectivas para la conservación del tapir centroamericano en México. Biodiversitas 99:12-16.

Naranjo, E. 2002. Population ecology and conservation of ungulates in the Lacandon Forest, Mexico. Tesis doctoral, Universidad de Florida. Gainesville, U.S.A.

Naranjo, E. 2009. Ecology and Conservation of Baird's tapir in Mexico. Tropical Conservation Science 2:140-158.

Nathan, R. 2008. An emerging movement ecology paradigm. Proceedings of National Academy of Sciences 49:19050-19051.

Noss, A., R. L. Cuellar, J. Barrientos, L. Maffei, E. Cuellar, R. Arispe, D. Rumiz, and K, Rivero. 2003. A camera trapping and radiotelemetry study of Lowland tapir (Tapirus terrestris) in Bolivian dry forest. Tapir Conservation 12:24-32

Pennington, T. D., and J. Sarukhán. 1998. Árboles Tropicales de México. UNAM. Fondo de Cultura Económica. Ciudad de México, México.

Pérez-Córtez, S., P. L. Enriquez, D. Sima-Panti, R. Reyna-Hurtado, and E. J. Naranjo. 2012. Influencia de la disponibilidad de agua en la presencia y abundancia de Tapirus bairdii en la selva de Calakmul, Campeche, Mexico. Revista Mexicana de Biodiversidad 83:753-761.

Reyna-Hurtado, R., E. Rojas-Flores, and G. W. Tanner. 2009. Home range and habitat preferences of white-lipped peccary groups (Tayassu pecari) in a seasonal tropical forest of the Yucatan Peninsula, Mexico. Journal of Mammalogy 90:1 199-1209.

Reyna-Hurtado, R., G. O’Farrill, D. Sima, M. Andrade, A. Padilla, and L. Sosa. 2010. Las aguadas de Calakmul, reservorios de fauna Silvestre y de la riqueza natural de México. Biodiversitas 93:2-7.

Reyna-Hurtado, R., C. A. Chapman, S. Calme, and E. Pedersen. 2012. Searching in heterogeneous environments: foraging strategies in the white-lipped peccary (Tayassu pecari). Journal of Mammalogy 93:124-133.

Seaman, D. E., And R. A. Powell. 1996. An evaluation of the accuracy of kernel density estimators for home range analysis. Ecology 77:2075-2085.

Silver, S. C., L. E. T. Ostro, L. K. Marsh, L. Maffel, A. J. Noss, and M. Kelly. 2004. The use of camera traps for estimating jaguar (Panthera onca) abundance and density using capture/recapture analysis. Oryx 38:148-154.

Submited: October 26, 2015

Reviewed: January 4, 2016

Accepted: May 21, 2016

Associated editor: Guillermo D’Elía 